\title{
The Balvanera Escudo
}

\section{Cristina Cruz González}

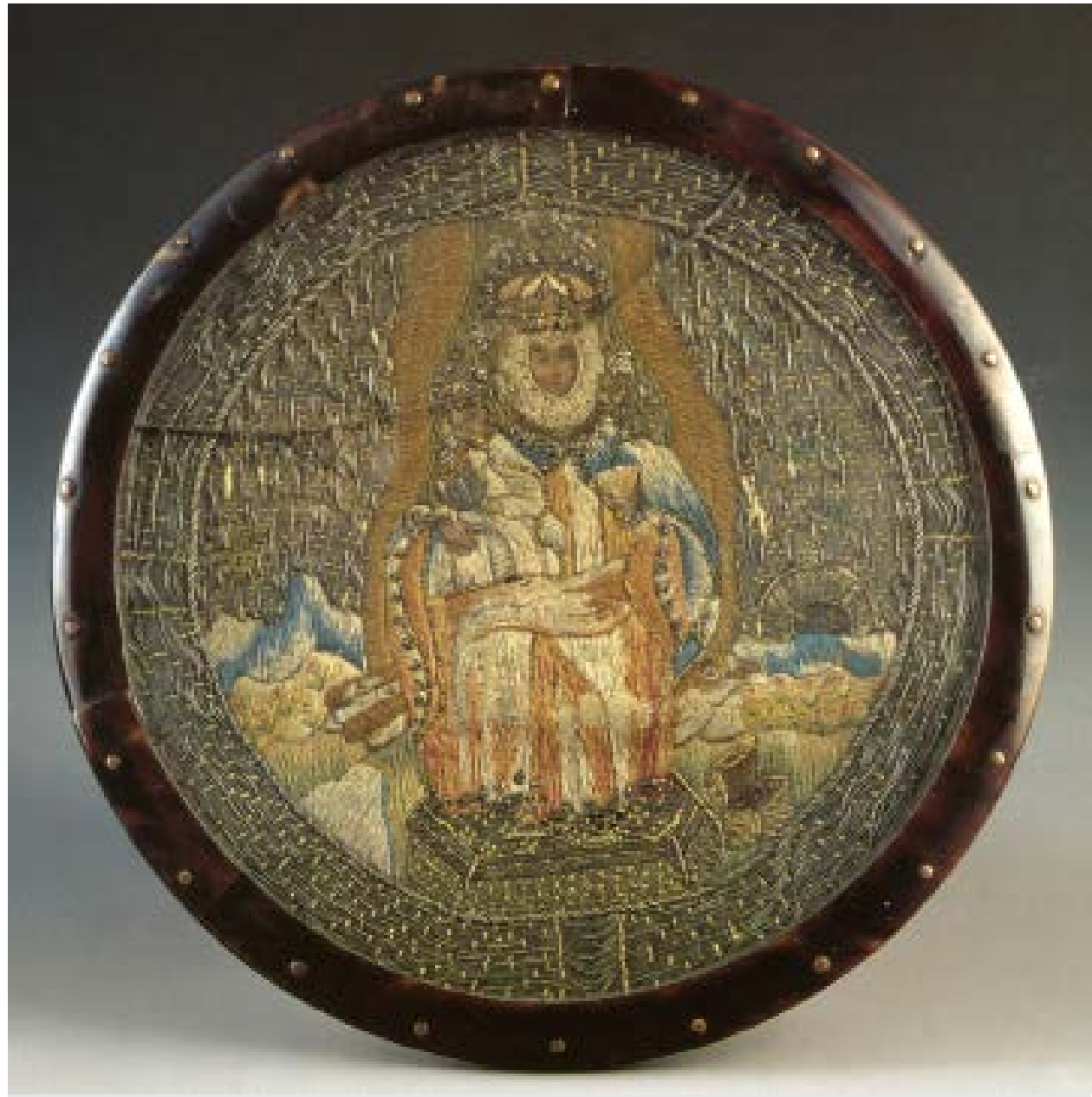

Fig. 1 The Balvanera Escudo, 18th century

In New Spain, Conceptionist and Jeronymite nuns adorned their habits with religious escudos, pictorial badges promoting their favored Marian devotions. ${ }^{1}$ Worn on the chest and measuring between six to ten inches, a striking example is housed at the Museo Franz Mayer in Mexico City (Fig. 1). ${ }^{2}$ The celebrated Virgin of Balvanera, a Romanesque sculpture from the Rioja region of Spain, is shown seated on a throne, lodged within a tree trunk, and surrounded by a vivid landscape. Set within a tortoiseshell frame, most of the surface is embroidered with silk and silver thread, betraying a feminine skill often mastered in the convent.

According to a fifteenth-century local account, the Virgin of Balvanera was crafted by Saint Luke, sent to Spain by Saint Peter, venerated in a chapel until 462, and then hidden in a hollow of an oak tree. Following the area's Reconquista, an angel led a hermit to the icon's discovery. Like the Virgin de Aranzazu, a medieval sculpture miraculously rediscovered in the Basque countryside, the Virgin of Balvanera 
announced early Christian piety while claiming regional identity. Expatriates from the Rioja established her devotion in colonial Mexico City: Conceptionist nuns oversaw the Balvanera convent and church while Riojanos funded a chapel in her honor on the grounds of the Franciscan monastery. ${ }^{3}$ Surviving devotional paintings by Juan Correa, José de Ibarra, and Miguel Cabrera were perhaps intended for these spaces.

The origin of the escudo is found in chivalric insignia, late medieval badges, religious jewelry, and the painted miniature, yet the form adopted larger proportions and vast importance in seventeenth- and eighteenth-century New Spain. ${ }^{4}$ As Elizabeth Perry argues, initial production in the 1630 s was a response to a set of partial reforms aimed at regulating religious dress. ${ }^{5}$ Archbishop Francisco Manso y Zuñiga instructed Conceptionist nuns to wear images of the Immaculate Conception on their habits and to forgo adornments-specifically "gold, stone, or enamel"-that seemed contrary to their vows. Wealthy nuns responded by commissioning painted escudos and replacing gold frames with tortoiseshell. By the mid-eighteenth century, the opulent emblems not only articulated a woman's religious affiliations, family fortune, and ethnic purity but also expressed her desire to influence political opinion. In a period of Bourbon reforms aimed at promoting austerity and a more collective, interior spirituality, the Mexican escudo became a mark of protest. Unreformed nuns proudly adopted and flaunted the object while reformed convents refused it. In the words of Perry, "the escudos de monjas had become both a product of imposed religious reform and an indigenous subversion of that reform."

While a nun was typically cloistered, her image was not. As the anxiety caused by the religious reforms intensified during the second half of the eighteenth century, nun portraiture-like the escudos themselves-became more prevalent and visually sumptuous (Fig. 2). ${ }^{7}$ Echoing the nun's visage, the escudo had the advantage: it was able to speak. Thus we locate the object not as a decorative accessory but as Derridean prosthetic-at once part of the body and outside of it. ${ }^{8}$ It conveys Otherness in its materiality and yet it is the part of the human figure that is most metonymic with its wearer, most intimately connected to her cosmopolitan identity, agency, and being. Appendage no longer-the Conceptionist detaching herself centuries ago-the prosthetic functions as a substitute for the absent nun and continues its life acquiring its own artificial supplements: a museum structure, glass vitrine, wall text, and catalog entry.

The Balvanera escudo offers us genealogical vision, yet the genre and the materiality betray a matrix in which foundation narratives and the rhetoric of purity are ceaselessly disrupted. It is not simply the case that our nun-Riojan or not-was a female religious in colonial Mexico, but that the insignia's silk, silver, and tortoiseshell stress the various and variegated communities of an early modern Hispanic world. What would a Baroque viewer see when looking into the Mexican escudo-mirror? Would they find China? Spain? Mexico? Refracted ambiguity. Silk production was both important and profitable in Puebla, Oaxaca, Granada, and Cordoba throughout the sixteenth century. While the establishment of the Manila Galleon in 1565 eventually led to the importation of less expensive silks from China, silk often arrived in the Americas not as finished product but as ribbon, trim, and thread to be transformed at its destination. Silver thread was also typically imported, this despite the fact that the presence of the mineral in any 


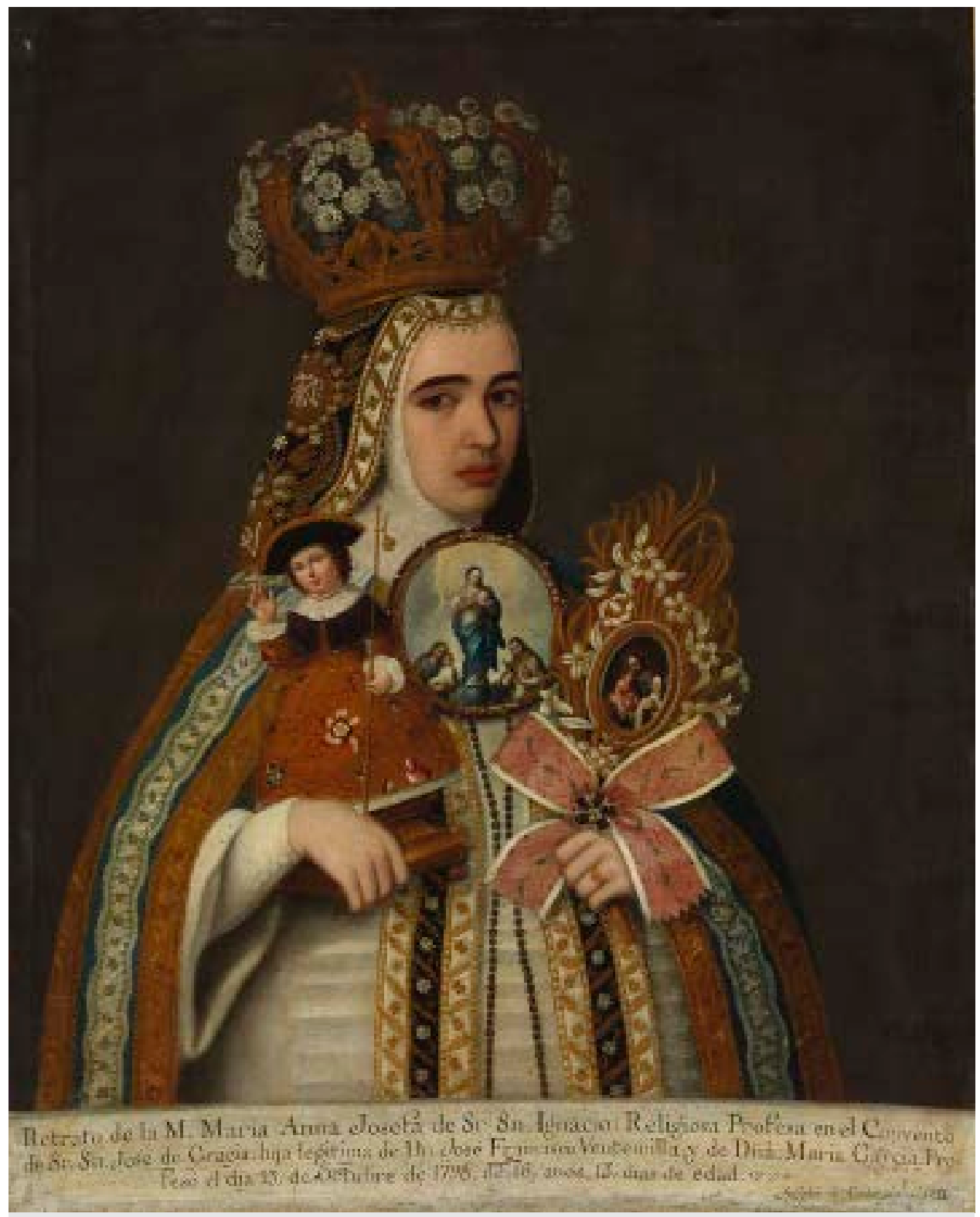

Fig. 2 José de Alcíbar, Portrait of Sor María Anna de San Ignacio, 1793

form communicated Spanish America's metallurgic and geo-cultural prestige. And while tortoiseshell could be found in Mexico's coastal waters, finished products such as fashionable combs and fans were frequently imported from Spain. Yet in eighteenthcentury Mexico, the raw material most likely originated in the southern Philippines or Indonesia. The Balvanera escudo is not only exotic and alluring, it is compellingly unknowable.

Exotic materials-in concept if not in origin-were prime sources for religious products. In the affluent cities of New Spain, metallic threads heightened the aura of specifically sacred settings, often appearing on priestly vestments, altar cloths, and the dress of a miraculous image. That the thread was used to delineate the Virgin of Balvanera was appropriate, therefore, and merited by the divine icon as much as by the nun's own 
affluence and social conceits. Similarly, tortoiseshell carried religious associations in colonial Mexico, often appearing in church spaces such as the pulpit in Querétaro's Santa Rosa Viterbo. ${ }^{9}$ Silver, perhaps the most abundant luxury item in a Baroque church, transformed lamps, chalices, censers, reliquaries, and ecclesiastical garments into magnificent treasures. The nun's badge, therefore, mimics both ecclesiastical prestige and the cosmopolitan church space, underscoring the power of the female religious body to consciously select and reject material referents in the demarcation of a simultaneously global and local identity.

(C) Cristina Cruz González

\section{Citation Guide}

1. Cristina Cruz González, "The Balvanera Escudo," Object Narrative, in Conversations: An Online Journal of the Center for the Study of Material and Visual Cultures of Religion (2014), doi:10.22332/con.obj.2014.50

González, Cristina Cruz. "The Balvanera Escudo." Object Narrative. In Conversations: An Online Journal of the Center for the Study of Material and Visual Cultures of Religion (2014). doi:10.22332/con.obj.2014.50

\section{Notes}

1. Conceptionist and Jeronymite convents restricted membership to Iberian-born women and American descendants of peninsular Spaniards (Creoles).

2. The Grandeur of Viceregal Mexico: Treasures from the Museo Franz Mayer, ex cat. (Houston and Mexico: Museum of Fine Arts, Houston and Museo Franz Mayer, 2002), 334-335.

3. For the Balvanera convent and church, see María Concepción Amerlinck de Corsi and Manuel Ramos Medina, Conventos de Monjas: Fundaciones en el México Virreinal (Mexico City: Grupo Condumex, 1995), 44-50.

4. Virginia Armella de Aspe and Guillermo Tovar de Teresa, Escudos de Monjas Novohispanas (Mexico City: Grupo Gusta, 1993); Martha Egan, "Escudos de Monjas: Religious Miniatures of New Spain,” Latin American Art 5, no. 4 (1994): 43-46; Elizabeth Perry, "Escudos de Monjas/Shields of Nuns: The Creole Convent and Images of Mexican Identity in Miniature" (Ph.D. diss., Brown University, 1999).

5. Perry, "Convents, Art, and Creole Identity in Late Viceregal New Spain," in Women and Art in Early Modern Latin America (Leiden: Brill Publishers, 2007), 321.

6. Ibid., 335 . 
7. Ibid.; James Córdova, The Art of Professing in Bourbon Mexico: Crowned-Nun Portraits and Reform in the Convent (Austin: University of Texas, 2014); Monjas coronadas: Vida conventual femenina en Hispanoamérica, ex cat. (Mexico City: INAH, 2003).

8. For Jacques Derrida, the term prosthetic is useful in examining language and the relationship between speech and writing. Similar to the "logic of the supplement," it simultaneously signals an addition and a lack, at once outside and inside, both extension and substitute (see, for example, Of Grammatology and Monolingualism of the Other: Or, the Prosthesis of Origin). David Wills further develops this notion and applies it more widely in Prosthesis (Palo Alto: Stanford University Press, 1995), emphasizing the always already fragmented body and the function of prosthetics-whether natural, mechanical, or technological-in the assimilation of otherness (what he calls an internal exteriorization). The Balvanera escudo is a prosthetic in that it articulates identity and assimilates otherness while disrupting the notion of an apriori integral body. Furthermore, the escudo is an artificial attachment with an afterlife, challenging the primacy of the human body by allowing for its own additions. See Wills, "Two Words Pro-Derrida," http://www.usc.edu/dept/comp-lit/tympanum/4/wills.html. For a concise overview of the concept in literary theory, philosophy, art history, media studies, and cyborg anthropology, see Sarah Coffey, "prosthesis," in The Chicago School of Media Theory, http://lucian.uchicago.edu/blogs/mediatheory/keywords/prosthesis/. A recent volume that explores many of these themes is The Prosthetic Impulse: From a Posthuman Present to a Biocultural Future, eds. Marquard Smith and Joanne Morra (Boston: The MIT Press, 2007).

9. Virginia Armella de Aspe, El carey en México (Mexico City: Grupo Multibanco Comermex, 1979).

\section{Yale}

Copyright 2016 Yale University All rights reserved. 